\title{
ESEJ RECENZYJNY
}

\author{
FELIKS TUSZKO (D)
}

Uniwersytet Warszawski

\section{UBOGACANIE: SOCJOLOGIA PRAGMATYCZNA O ŹRÓDŁACH WARTOŚCI TOWARÓW W KAPITALIZMIE ${ }^{1}$}

Luc Boltanski, Arnaud Esquerre, Enrichment: A critique of commodities, Polity Press, Cambridge 2020, ss. 471.

\section{Streszczenie}

Niniejszy esej recenzyjny poświęcony książce Luca Boltanskiego i Arnauda Esquerre'a Enrichment opisuje nowatorstwo pragmatycznego strukturalizmu, zwracając uwagę na wspólistnienie różnych sposobów utowarowienia przedmiotów. Zaproponowana przez francuskich socjologów rama teoretyczno-metodologiczna otwiera nowe możliwości do analizowania kondycji współczesnego kapitalizmu - jak twierdzą Boltanski i Esquerre współcześnie zysk jest często osiagany w procesie „ubogacania” przedmiotów. W eseju powyższe ustalenia zostały umieszczone w szerszym kontekście rozwoju programu socjologii pragmatycznej, wskazano na ich oryginalność i znaczenie dla socjologii w ogóle oraz ich potencjalne słabości i ograniczenia.

Słowa kluczowe: socjologia pragmatyczna, socjologia ekonomiczna, wartościowanie, utowarowienie, kapitalizm

1 Esej powstał w wyniku realizacji projektu badawczego o $\mathrm{nr}$ 2019/35/N/HS6/01634 finansowanego ze środków Narodowego Centrum Nauki. 
Kapitalizm po raz kolejny zmienił swoje oblicze - twierdzą Luc Boltanski i Arnaud Esquerre. Na stronach Enrichment starają się przekonać czytelników, że współcześnie zysk jest generowany inaczej niż dotychczas. Wykorzystują narzędzia socjologii pragmatycznej, aby podważyć dominującą koncepcje utowarowienia i uwidocznić, że kapitalizm w tym względzie jest bardziej zróżnicowany. Pokazują, że dziś, po tym jak państwa rozwinięte przeszły proces deindustrializacji, mamy do czynienia z zyskującym na znaczeniu fenomenem gospodarki ubogacania (enrichment economy). Czym właściwie jest gospodarka ubogacania i czy istotnie stanowi znaczący fenomen? Na czym zasadza się oryginalność tego ujęcia? Co dla socjologii wynika z zawartych w Enrichment propozycji teoretycznych? Wokół tych pytań koncentruje się niniejszy tekst.

Enrichment, co uzasadnię jeszcze w dalszej części rozważań, należy uznać za ważną pracę z punktu widzenia formowania się programu francuskiej socjologii pragmatycznej. Doprecyzowujący przymiotnik „francuska” ma podkreślać odrębność tego programu od amerykańskiego pragmatyzmu. Pomimo niektórych elementów zbieżnych oba programy były rozwijane osobno. Boltanski nigdy nie ustosunkował się do klasyków pragmatyzmu: Williama Jamesa, Charlesa H. Cooleya, Johna Deweya i Georga H. Meada [por. Bogusz 2014; Quéré, Terzi 2014].

Zapoczątkowana na początku lat 90. przez Boltanskiego socjologia pragmatyczna jest $\mathrm{w}$ polskich naukach społecznych prawie nieobecna. Wyjaśnień można by szukać wiele, jednak wydaje się, że najbardziej prawdopodobne jest to najbardziej prozaiczne. Pomimo że prace tworzone lub współtworzone przez Boltanskiego zdobyły międzynarodowe uznanie, a myśl w nich zawarta stała się podstawą licznych badań, wciąż nie doczekaliśmy się ich polskich wydań. Najważniejsze - L'amour et la justice comme compétences, De la justification, Le nouvel esprit du capitalisme, De la critique - ukazały się w 1990, 1991, 1999 i 2009 roku. Braku polskich tłumaczeń nie można zatem usprawiedliwiać niedostatkiem czasu. Trzeba natomiast odnotować opublikowany w „Kronosie” fragment Nowego ducha kapitalizmu [Boltanski, Chiapello 2015] oraz artykuł Kolekcjonerstwo jako nowa forma kapitalizmu. Kapitalizacja przeszłości i jej skutki [Boltanski, Esquerre 2015], a także, co ciekawe, dostępny jedynie w języku polskim esej Od rzeczy do dzieła. Procesy atrybucji i nadawania wartości przedmiotom [Boltanski 2011a], opublikowany w zbiorze Wieczna radość. Ekonomia polityczna społecznej kreatywności. Owa wyrywkowość nie ułatwia mojego zadania. Brak bowiem ogólnie przyjętych tłumaczeń kluczowych dla socjologii pragmatycznej pojęć. Sprawę utrudniają dodatkowo omówienia poszczególnych prac, których autorzy thumaczyli te pojęcia po swojemu, bez uwzględniania 
dotychczas używanej terminologii [Kozłowski 2015; Kuźniarz 2015; Lewicki 2019; Stachowiak 2014; Templewicz 2014].

Tytułowe enrichissement (ang. enrichment) zdecydowałem się przetłumaczyć jako 'ubogacanie'. Uzasadnienie tego wyboru posłużyć może za wprowadzenie do recenzji pracy Boltanskiego i Esquerre'a. Słowo „ubogacanie” opisuje proces, w którego konsekwencji przedmiot staje się wartościowszy. Dzieje się tak niekoniecznie dlatego, że zmianie ulegają jego materialne właściwości, lecz przede wszystkim dlatego, że jest przez ludzi bardziej ceniony. Termin „ubogacanie” jest lepszy niż ,wzbogacanie”, ponieważ zwraca uwagę na niematerialny aspekt tego procesu. Wraz z ubogacaniem przedmiotów ubogacani są ich właściciele. W związku z tym w centrum gospodarki ubogacania znajdują się bogaci, którzy działają na rzecz tego, by posiadane przez nich drogie przedmioty były jeszcze cenniejsze. Inaczej niż w gospodarce industrialnej, gdzie zysk wynikał z wyzysku robotników, w gospodarce ubogacania zysk jest generowany z bogactwa. Nie znosi to oczywiście istnienia wyzysku, ale przybiera on inną, bardziej dyskretną formę.

Ostatnie 50 lat w krajach rozwiniętych to dla Boltanskiego i Esquerre'a postępujące procesy deindustrializacji, rozrostu międzynarodowych korporacji oraz odchodzenia od sztywnych form organizacji i zarządzania na rzecz elastycznych form projektowych. Zawarte w Enrichment spostrzeżenia nie są nowe, zostały bowiem opisane wcześniej $\mathrm{w}$ The new spirit of capitalism przez Boltanskiego i Ève Chiapello [2007]. Bazując na Weberowskim pojęciu ducha kapitalizmu, rozumianym jako zestaw przekonań i praktyk uprawomocniających aktualny porządek ekonomiczny jako sprawiedliwy, autorzy ci pokazują, że krytyka fordyzmu końca lat 60 . doprowadziła do wyłonienia się nowego ducha, którego esencją jest jednostkowa odpowiedzialność za powodzenie niekończącego się ciagu projektów. Choć The new spirit of capitalism i Enrichment analizują zbliżony okres w historii, to robią to z odmiennych perspektyw. Pierwsza z książek koncentruje się na stronie subiektywnej i motywacyjnej jednostek. Druga kieruje uwagę w stronę towarów i tego, jak wytwarzana jest ich wartość. Przesunięcie nie oznacza jedynie zmiany przedmiotu zainteresowania, lecz implikuje także istotną modyfikację rozwijanej przez Boltanskiego perspektywy teoretycznej-od socjologii pragmatycznej w stronę pragmatycznego strukturalizmu.

Przejście od fordyzmu do postfordyzmu miało przemożny wpływ na światowy krajobraz gospodarczy. W państwach rozwiniętych zamykano duże zakłady przemysłowe i przenoszono je do państw rozwijających się. Pozamykane zostały fabryki, wymarły skupione wokół nich miasteczka, wzrosła migracja do dużych miast. Skala zjawiska jest wyraźna - w przypadku Francji w okresie od 
1968 roku do 2010 roku zatrudnienie w sektorze przemysłowym zmniejszyło się o 40 proc. [Boltanski, Esquerre 2020: 11]. Zjawisko offshoringu nie oznaczało spadku przychodów państw rozwiniętych. Miejsce przemysłu zastapiły bardziej dochodowe sektory - finansowy i technologiczny. Przemiany gospodarcze były już wcześniej analizowane za pomocą pojęć kapitalizmu kognitywnego [Moulier Boutang 2011] i pracy niematerialnej [Lazzarato 2006]. Oryginalność podejścia Boltanskiego i Esquerre'a, różnego od dwóch wcześniej wymienionych, bierze się stąd, że nie skupiają się oni na produkcji rozumianej jako wartość wytwarzana przez pracę, a na wartości rozumianej jako pochodna procesów wartościowania.

Aby opisać wytwarzanie wartości we współczesnym kapitalizmie, Boltanski i Esquerre korzystają z narzędzi socjologii pragmatycznej. Jej kluczowym założeniem jest ujęcie ludzi jako jednostek refleksyjnych, uzasadniających swoje działania przez odniesienie ich do różnorodnych porządków moralnych i posiadających zdolności krytyki (critical capacity) [Boltanski, Thévenot 2006; Boltanski 2011b]. To w tym kontekście socjologia pragmatyczna bada, w jaki sposób sprawcze jednostki angażują się w wytwarzanie porządku społecznego. Porządek ten nie jest stały, lecz nieustannie wytwarzany i fluktuujący - w toku wartościowań zmieniają się hierarchie między ludźmi, rzeczami, działaniami i stanami świata. Procesy wartościowania nie są przypadkowe - są strukturyzowane przez instytucje [Boltanski 2011b], które w pierwszym rzędzie mają charakter semantyczny: pomagają ludziom określić "whatness of what is" - czym jest to, co jest. Instytucja pozwala ludziom z nieskończonego chaosu rzeczywistości wybrać te elementy, na które „spogląda się po raz drugi” i uznaje je za znaczące.

W centrum analizy w Enrichment znalazły się towary, których kondycja, jak twierdzą autorzy książki, mówi wiele o kondycji kapitalizmu w ogólności. Boltanski i Esquerre przyjmują szeroką definicję towaru, uznając, że jest nim wszystko, czemu w momencie wymiany zostaje przypisana cena. Wartość jest z kolei rozumiana jako urządzenie (device) do uzasadniania bądź krytyki ceny towaru. Jako że w toku procesów utowarowienia wytworzona zostaje wartość towaru, należy utożsamić je z procesami wartościowania. Za Arjunem Appaduraiem [2013] autorzy Enrichment postrzegają utowarowienie jako proces ciagły. Przedmioty można opisać z perspektywy ich biografii towarowych, czyli z perspektywy nieustannych przemian ich statusu jako towaru w toku cyrkulacji. Towar w ciągu swojego życia poddawany jest testom, w których, w zależności od wyniku, jego wartość jest potwierdzana lub odrzucana. Podstawowym testem w świecie towarowym jest transakcja. W czasie transakcji zderzane są ze sobą różne uzasadnienia i krytyki ceny towaru. W efekcie wartość towaru zostaje usankcjonowana w świecie cen. 
Boltanski i Esquerre instytucje, które strukturyzują wartościowanie towarów, grupują pod pojęciem form waloryzacji (forms of valorization). Formy waloryzacji są strukturami dyskursywnymi, które pozwalają ludziom na połączenie obiektu z odpowiednim sposobem jego wartościowania. Dzięki owym strukturom ludzie są zdolni do zaangażowania w wymianę towarową - do szacowania i uzasadniania cen w momencie transakcji. Autorzy Enrichment identyfikują cztery formy waloryzacji. Najważniejszymi dzielącymi je osiami są: różnicowanie (jak można uwydatnić różnice między innymi towarami, tak aby były znaczące), czasowość (jak cena może zmieniać się w czasie) oraz sposób prezentacji towaru (analityczny bądź narracyjny). Tak więc charakterystyczna dla gospodarki przemysłowej jest forma standardu (standard form), w której towary są produkowane masowo. Takie towary z biegiem czasu tracą wartość, by ostatecznie na samym końcu zamienić się w pozbawiony wartości odpad. Drugą formą jest forma kolekcji (collection form ) - należą do niej przedmioty rzadkie, unikatowe i autentyczne. Wartościowane są pod kątem bliskości z ważnymi osobami, miejscami i wydarzeniami z przeszłości. Towary należące do tej formy są wyjmowane z porządku czasu i traktowane jak wieczne. Ich wartość zależy od miejsca w kolekcji czy w serii, do której należą - od tego, jak wielki brak dla określonej całości wywołałoby wyjęcie z niej konkretnego przedmiotu. Forma trendu (trend form) odnosi się do rzeczy, których wartość bierze się z ich znaczenia dla teraźniejszości. Przedmioty należące do tej formy są wartościowane pod kątem ich relacji ze znanymi osobami lub uznanymi markami. Ostatnią, czwartą formą jest forma aktywów (asset form) - czyli taka, w której towary są zakupywane w celu późniejszej odsprzedaży z zyskiem. Przedmiot jest wartościowany w relacji do metaceny (metaprice) - $\mathrm{w}$ tym przypadku tego, ile potencjalnie będzie wart $\mathrm{w}$ przyszłości. Ze względu na to, że podstawową formą istnienia aktywów jest pieniądz, wszystkie inne aktywa są wartościowane pod kątem ich płynności.

Wartość towarów jest wytwarzana w toku procesów wartościowania - argumentują Boltanski i Esquerre. Różnorodność tych procesów sprawia, że nie mamy do czynienia z jednym sposobem utowarowienia, a zatem z jednym źródłem wartości i zysku, tylko z ich wielością. Założenie to stanowi istotną kontrpropozycję wobec koncepcji towaru u Marksa [1867(1951)], który wiązał wartość z „substancją wartościotwórczą”, czyli pracą. Jak już wcześniej pokazałem, wielość nie oznacza przypadkowości - istnieją struktury dyskursywne, które uspójniają i utrwalają wartościowanie towarów. Gdyby wartościowanie nie było w żaden sposób strukturyzowane, to niepewność co do wartości przedmiotów byłaby zbyt wielka, by umożliwić wymianę rynkową. Opisane w Enrichment 
formy waloryzacji oznaczają uznanie przez socjologię pragmatyczną znaczenia tych struktur, tym samym dając początek pragmatycznemu strukturalizmowi.

Ludzie wartościują przedmioty, odnosząc się do mniej lub bardziej utrwalonych i rozpowszechnionych form waloryzacji. Jednocześnie towary nie są przypisane do jednej formy waloryzacji. Przemieszczanie się pomiędzy poszczególnymi formami jest naturalne dla biografii wielu towarów, a co więcej, może stanowić istotne źródło wzrostu ich wartości. Autorzy Enrichment, odwołując się do prac historyka Ferdynanda Braudela, pokazują, że przemieszczanie może prowadzić do ubogacania towaru - nie musi to być koniecznie przemieszczenie geograficzne, ale przemieszczenie niematerialne, polegające na zmianie sposobu wartościowania. Produkowany seryjnie niedrogi długopis ma krótki życiorys - wraz z tym, jak ubywa z niego tuszu, zbliża się do statusu śmiecia. Gdy okaże się jednak, że pisząca nim ręka należała do noblisty, długopis, mimo swojej praktycznej bezużyteczności, może zostać wyjęty spod niszczącego działania czasu i być wartościowany w odniesieniu do jego relacji ze sławnym właścicielem.

Powyższy przykład jest o tyle dobry, że opisuje charakterystyczny dla gospodarki ubogacania ruch towarów między formami waloryzacji - od formy standardu i trendu w kierunku formy kolekcji. Dwie pierwsze formy waloryzują aktualność towarów - zatem charakterystyczne jest ich przemijanie i utrata wartości. Przemieszczanie towarów do formy kolekcji jest dla nich drugim życiem - pozbawione pierwotnej funkcji zostają ponownie docenione. Dostrzeżenie tego zjawiska ujawnia cechy wyróżniające gospodarki ubogacania, jakimi są eksploatowanie przeszłości oraz zwiększanie wartości przedmiotów, które już istnieją.

Choć Boltanski i Esquerre przekonują że gospodarka ubogacania jest istotnym fenomenem, odpowiedzialnym za produkcję znacznej ilości bogactwa, to nie są w stanie oszacować jego skali. Dlatego ich argumenty mają przede wszystkim charakter jakościowy. Czytelnik, chcąc ocenić znaczenie tego fenomenu, powinien polegać na swoim „wyczuciu rzeczywistości społecznej” [Boltanski, Esquerre 2020: 17]. Powstanie gospodarki ubogacania autorzy Enrichment widzą jako sprzężenie trzech procesów: wzrostu rynku dóbr luksusowych, rekonstruowania dziedzictwa historycznego oraz rozwoju turystyki. W pierwszej części książki autorzy uświadamiają czytelnikowi, czym jest gospodarka ubogacania, sięgając po takie przykłady, jak rynek dzieł sztuki, nieruchomości i innych dóbr luksusowych. O niektórych z tych dóbr możemy przeczytać na przykład w rozdawanych w samolotach darmowych magazynach. Znajdziemy tam informacje o autentycznych miejscach w kraju, do którego zmierzamy - o starej rodzinnej winnicy, o małym wyrafinowanym bistro czy o kunsztownym regionalnym rzemiośle. Obejrzymy w nich także reklamy ekskluzywnych zegarków, perfum i biżuterii. 
Z ubogacaniem zetkniemy się zarówno w zachodnich metropoliach, jak i na zrewitalizowanej prowincji. Za pieniądze państwowe albo unijne rekonstruuje się dziedzictwo historyczne poszczególnych regionów, by przez uwydatnienie ich walorów autentyczności i unikatowości napędzić rozwój poszczególnych miejsc. W tym celu tworzy się muzea i inne instytucje zajmujące się przywracaniem pamięci. Organizuje się wokół tego dziedzictwa wydarzenia cykliczne i festiwale. Wszystko to ma na celu zapewnienie wzrostu turystyki w danym regionie. Chodzi tu o turystykę kulturową, wartościującą autentyczność i rzadkość, sytuowaną w opozycji do degradującej środowisko i lokalne społeczności turystyki masowej.

Na podstawie powyższego portretu wyraźnie widać, co jest cenione w gospodarce ubogacania: to, co autentyczne, oryginalne, unikatowe i wyjątkowe. Jakości te są wydobywane w sposób narracyjny, łącząc istniejący w teraźniejszości przedmiot z przeszłością. Przedmioty są wartościowane pod kątem posiadanej przez nie siły pamięciowej (memorial force), czyli ich zdolności do przywoływania wydarzeń, miejsc i osób. Narracje zawsze będą miały element fikcyjności - są bowiem swoistymi fabułami, które w arbitralny sposób ustalają relacje pomiędzy składającymi się na nie elementami. Fikcyjność narracji łatwo zrozumieć, analizując próby przywracania zapomnianych i bezwartościowych przedmiotów z przeszłości.

Nasuwa się tu pytanie, w jaki sposób w ramach formy kolekcji mogą być wartościowane przedmioty powstające współcześnie, które są pozbawione przeszłości, do której można byłoby się odwołać. „Nic nie wydaje się bardziej współczesne niż sztuka współczesna, nie tylko dlatego, że jest kształtowana w teraźniejszości, ale także dlatego, że szczyci się tym, iż jest zwrócona ku przyszłości" - zauważają Boltanski i Esquerre [2020: 213]. Żeby móc podtrzymać argument, że źródłem wartości w formie kolekcji jest eksploatowanie przeszłości, autorzy Enrichment przekonują, że wartościowanie dzieł sztuki stanowi rodzaj retroaktywnej operacji. Osoba oceniająca dzieło sztuki wyobraża sobie znaczenie dzieła w przyszłości i z tej właśnie perspektywy spogląda na teraźniejszość, tak jakby należała już do przeszłości.

Konfuzję u czytelnika może budzić to, że opisana przez Boltanskiego i Esquerre'a retroaktywna operacja do złudzenia przypomina sposób wartościowania przedmiotów w formie aktywów. Aktywa są bowiem oceniane „pod kątem przychodów, które mogą wygenerować w przyszłości, tym samym zakłada to ustalenie momentu, w którym dochody te zostaną uzyskane" [Boltanski, Esquerre 2020: 247]. Choć autorzy Enrichment argumentuja, że forma kolekcji zakłada eksploatację przeszłości, a forma aktywów przyszłości, to w rzeczywistości wartościowania $\mathrm{w}$ obu formach są spekulacjami na temat stanu przyszłego. 
Retroaktywny ruch jest $\mathrm{w}$ istocie niczym innym jak próbą antycypacji. Różnica między obydwoma formami jest wobec tego subtelna i dotyczy przede wszystkim trwałości obiektów. W formie kolekcji przedmioty traktowane są tak, jakby były nieśmiertelne. $Z$ kolei forma aktywów pozwala na bardziej pragmatyczne podejście i dostosowanie oczekiwania wobec żywotności obiektu do potencjału wzrostu jego wartości. Nie sprawia to jednak, że wartościowanie w ramach formy aktywów nie może odwoływać się do trwałości przedmiotów - według mnie nie ma tu sprzeczności.

Omówione wyżej nieoczywiste podobieństwo w sposobach wartościowania sygnalizuje istnienie szerszego problemu teoretycznego, czyli niejasnych zależności pomiędzy poszczególnymi formami waloryzacji. Co się dzieje, gdy przedmiot jest wartościowany jednocześnie $\mathrm{w}$ ramach dwóch albo i większej liczby form waloryzacji? Czy wszystkie formy wartościowania mają ten sam status i czy łączy je w związku z tym relacja konkurencji, czy symbiozy? Czy możliwe jest wyznaczanie granic poszczególnych form, a jeżeli tak, do których form przynależą te granice? Boltanski i Esquerre nie udzielają odpowiedzi na te pytania. Owe niejasności są konsekwencją przyjętej perspektywy teoretycznej, która zakłada współistnienie wielości sposobów wartościowania. Autorzy Enrichment w sposób analityczny identyfikują cztery z nich, czyli te, które uznają za poddające się obserwacji i istotne. Nie oznacza to jednak, że nie istnieją inne formy waloryzacji.

Z identycznym problemem Boltanski i Thévenot [2006] zmierzyli się w On justification, wyodrębniając sześć porządków wartości (albo, w zależności od thumaczenia, sześć wspólnot, miast czy światów): rynkowy (handlowy), przemysłowy, obywatelski, domowy, sławy (reputacji), natchniony. Dlaczego dokładnie tyle porządków, a nie więcej albo mniej? Tyle zostało zidentyfikowanych w procesie analizy, ale nie oznacza to, że nie istnieje ich więcej. Dlatego też dodanie siódmego porządku - sieciowego - w The new spirit of capitalism [Boltanski, Chiapello 2007] nie zagrażało spójności teoretycznej - wręcz przeciwnie, było jej naturalną konsekwencją. W On justification problem relacji między porządkami wartości potraktowano skrupulatnie - wszystkie możliwe kombinacje relacji między porządkami zostały rozpisane w formie pola możliwości krytyki (critical matrix). Niestety w Enrichment autorzy nie podjęli próby systematyzacji zależności między formami waloryzacji - wskazali jedynie na podobieństwa i różnice, które mogą, ale nie muszą, sprzyjać odpowiednio wzmacnianiu lub osłabianiu wartości poszczególnych towarów.

Boltanski i Esquerre nie odpowiadają także na pytanie o to, czy formy mają identyczny status, czy też są względem siebie konkurującymi uniwersalnościami. 
To o tyle ważne, że z analizy przedstawionej w Enrichment wynika, że niektóre formy mogą doskonale współistnieć ze sobą. Wspomniany wcześniej przykład współczesnych dzieł sztuki dobrze oddaje, w czym rzecz. Dzieło sztuki może być jednocześnie elementem kolekcji i aktywem. Jak argumentuje Nancy Fraser [2017], autorzy Enrichment, nie pochylając się nad statusem i relacjami form waloryzacji, przeoczyli istotną obserwację: w sfinanansjalizowanym świecie wszystko może zostać przekształcone w aktywa. Znaczenie aktywów dla kapitalizmu zostało przez Boltanskiego i Esquerre'a właściwie pominięte - poświęcono im tylko dwanaście z prawie pięciuset stron książki. Jest to istotny brak pracy, sugerujący wyrywkowość przedstawionego ujęcia. Enrichment nie jest więc książką w sposób wyczerpujący diagnozującą działanie współczesnego kapitalizmu - skupia się jedynie na jego wyimku, jakim jest gospodarka ubogacana. Boltanski i Esquerre przekonują, że jest to znaczący wyimek, tylko że w tej kwestii musimy przede wszystkim polegać na własnym „wyczuciu rzeczywistości społecznej”.

Pomimo zarysowanej krytyki ujęcia form waloryzacji Enrichment pozostaje ważną i oryginalną propozycją. Na poziomie wniosków empirycznych praca Boltanskiego i Esquerre'a dostarcza poważnych argumentów dotyczących mechanizmów reprodukcji bogactwa i przyczyn wzrostu nierówności majątkowych. We współczesnym kapitalizmie bogactwo jest wytwarzane bardzo często w wyniku ubogacania tego, co już ma dużą wartość. Z tej perspektywy wyzysk wciąż istnieje, ale jak pisałem wcześniej, przybiera dyskretniejszą formę. W ubogacanie posiadanego przez miliardera dzieła sztuki bezinteresownie angażuje się liczne grono pośredników - widzów, krytyków, historyków sztuki czy kuratorów. Mimo swojej kolektywnej pracy nie otrzymują żadnego udziału w dziele, pozwalającego na czerpanie zysku z wytworzonej wartości.

Wkład teoretyczno-metodologiczny Enrichment wydaje się nie mniejszy niż empiryczny. Propozycja pragmatycznego strukturalizmu daje wyjątkową możliwość wglądu w świat towarowy. Analiza struktur utowarowienia pozwala znacznie lepiej niż narzędzia klasycznej ekonomii czy ujęcie marksowskie na wyjaśnienie wewnętrznego zróżnicowania świata towarów. Dobrze to widać na przykładzie dzieł sztuki, czyli towarów unikatowych, które z perspektywy klasycznej ekonomii charakteryzuje nieustanne napięcie między niewspółmiernością dóbr kulturowych a współmiernością towarów. Wkład Boltanskiego i Esquerre'a polega więc na „rozbrojeniu” towarów i pokazaniu, że przedmioty mogą być utowarowione na różne sposoby, co więcej, że przedmioty tego samego rodzaju mogą być wartościowane odmiennie. Dla badań nad sztuką oznacza to, że nie wszystkie dzieła są wartościowane w identyczny sposób, w ramach 
tych samych form waloryzacji. Dzieła sztuki cyrkulują w zróżnicowany sposób, przechodzą w konsekwencji przez inne wartościowania i inne testy potwierdzające ich wartość. Sądzę więc, że dokładniejsze przyjrzenie się zróżnicowaniu procesów wartościowania potencjalnie może dobrze wyjaśnić różnice w wartości poszczególnych dzieł, a tym samym powiedzieć coś ważnego o mechanizmach różnicowania pozycji ich wytwórców i wytwórczyń.

Napisane w przeciagu ostatnich trzydziestu lat prace Boltanskiego i jego współpracowników weszły do kanonu współczesnej socjologii. Rozwijany oryginalny program socjologii pragmatycznej stał się inspiracją i teoretyczną podstawą licznych badań w obszarach socjologii ekonomicznej, socjologii polityki, socjologii pracy, socjologii wartościowania, socjologii organizacji czy socjologii sztuki. Dlatego dobrze by się stało, gdyby opublikowanie Enrichment, książki wnoszącej do nauk społecznych wartościowe narzędzia teoretyczno-metodologiczne, okazało się motywacją do przygotowania tłumaczeń najważniejszych prac socjologii pragmatycznej, a tym samym do uporządkowania w języku polskim jej, dziś chaotycznej, siatki pojęciowej.

\section{BIBLIOGRAFIA}

Appadurai Arjun. 2013. Introduction: Commodities and the politics of value. In: The social life of things: Commodities in cultural perspective, A. Appadurai (ed.), 3-63. Cambridge: Cambridge University Press.

Bogusz Tanja. 2014. Why (not) pragmatism? In: The spirit of Luc Boltanski: Essays on the "pragmatic sociology of critique”, S. Susen, B.S. Turner (eds.), 91-128. London, New York: Anthem Press.

Boltanski Luc. 1990. L'amour et la justice comme compétences: Trois essais de sociologie de l'action. Paris: Editions Métailié.

Boltanski Luc. 2009. De la critique: Précis de sociologie de l'émancipation. Paris: Gallimard.

Boltanski Luc. 2011a. Od rzeczy do dzieła. Procesy atrybucji i nadawania wartości przedmiotom. W: Wieczna radość. Ekonomia polityczna społecznej kreatywności, J. Sowa (red.), 17-47. Warszawa: Fundacja Nowej Kultury Bęc Zmiana.

Boltanski Luc. 2011b. On critique: A sociology of emancipation. Cambridge: Polity Press.

Boltanski Luc, Ève Chiapello. 1999. Le nouvel esprit du capitalisme. Paris: Gallimard.

Boltanski Luc, Ève Chiapello. 2007. The new spirit of capitalism. London: Verso.

Boltanski Luc, Ève Chiapello. 2015. „Nowy duch kapitalizmu”. Kronos 2(33): 5-92.

Boltanski Luc, Arnaud Esquerre. 2015. „Kolekcjonerstwo jako nowa forma kapitalizmu. Kapitalizacja przeszłości i jej skutki”. Kronos 2(33): 124-151.

Boltanski Luc, Arnaud Esquerre. 2020. Enrichment: A critique of commodities. Cambridge: Polity Press.

Boltanski Luc, Laurent Thévenot. 1991. De la justification: les économies de la grandeur. Paris: Gallimard. 
Boltanski Luc, Laurent Thévenot. 2006. On justification: Economies of worth. Princeton: Princeton University Press.

Fraser Nancy. 2017. “A new form of capitalism?”. New Left Review 106: 57-65.

Kozłowski Michal. 2015. „Boltanskiego stawki socjologiczne”. Kronos 2(33): 121-23.

Kuźniarz Bartosz. 2015. „Zła nieskończoność i wahadło krytyki. O kapitalizmie według Luca Boltanskiego". Kronos 2(33): 93-111.

Lazzarato Maurizio. 2006. Immaterial labour. In: Radical thought in Italy: A potential politics, P. Virno, M. Hardt (eds.), 133-47. Minneapolis: University of Minnesota Press.

Lewicki Mikołaj. 2019. „Ekonomia wartości w gospodarstwie domowym”. W: tegoż, Społeczne zycie hipoteki, 51-59. Warszawa: Wydawnictwo Naukowe Scholar.

Marks Karol. 1867 [1951]. Kapitat. T. 1. Warszawa: Książka i Wiedza.

Moulier Boutang Yann. 2011. Cognitive capitalism. Cambridge: Polity Press.

Quéré Louis, Cédric Terzi. 2014. Did you say 'pragmatic'? Luc Boltanski’s sociology from a pragmatist perspective. In: The spirit of Luc Boltanski: Essays on the 'pragmatic sociology' of critique, S. Susen, B.S. Turner (eds.), 91-128. London, New York: Anthem Press.

Stachowiak Jerzy. 2014. „O koncepcji nowego ducha kapitalizmu w ujęciu Luca Boltanskiego i Ève Chiapello". Przegląd Socjologiczny 63(4): 9-43.

Templewicz Karol. 2014. De la justification: Nowe spojrzenie na społeczeństwo? W: Oprogramowanie rzeczywistości społecznej, M. Gdula, L.M. Nijakowski (red.), 235-264. Warszawa: Wydawnictwo Krytyki Politycznej.

Feliks Tuszko

\title{
ENRICHMENT: A PRAGMATIC SOCIOLOGY ON THE SOURCES OF COMMODITY VALUE IN CAPITALISM
}

\begin{abstract}
This review essay of Luc Boltanski's and Arnaud Esquerre's book "Enrichment" describes the novelty of pragmatic structuralism's attention to the coexistence of the multiple ways in which objects can be commodified. The theoretical and methodological framework proposed by the French sociologists introduces new possibilities for analyzing the condition of contemporary capitalism - as Boltanski and Esquerre argue that nowadays profit is often achieved through a process of object enrichment. The essay places the above findings in the broader context of the development of the pragmatic sociology programme and points out their originality and wider significance for sociology, as well as their potential weaknesses and limitations.
\end{abstract}

Keywords: pragmatic sociology, economic sociology, valuation, commodification, capitalism 